\title{
Dialogue among pre- and post-genetic revolution civilisations
}

\author{
DONRICH JORDAAN*
}

\begin{abstract}
The genetic revolution will have a profound impact on human society and therefore on the public policy environment. This article aims to describe the public policy paradigms and paradigm shifts that will determine the framework for dialogue public policy discourse - on an abstract conceptual level. The genetic revolution will place the determination of children's genetic endowment squarely within the domain of human control, and hence the responsibility for a new child's genetic endowment will shift from nature to man. In order for this paradigm shift to take place in public policy, it must be realised that 'naturalness' has no ethical significance. A further major obstacle in the way of this paradigm shift is the mystification paradox: as the genetic revolution is increasing our scientific understanding of the fundamental mechanisms of life, so these mechanisms are being demystified; but simultaneously a variety of factors, for instance the fact that this new science seems to penetrate the very essence of life, as well as the existence of a new esoteric genetic terminology that is inaccessible to the general public mystify genetics. Education provides the essential platform for dialogue among the pre- and post-genetic revolution civilisations.
\end{abstract}

Keywords: Genetic revolution, pre- and post-revolution, civilisation, policy paradigms, mechanisms of life, genetics, nature and nurture, open society, education.

\section{Introduction}

\subsection{Background: The genetic revolution}

Since the dawn of our species, humankind has steadily acquired knowledge about itself and its surroundings. The mystery that surrounded life in prehistoric times has progressively been replaced by scientific understanding. Ours has been - and is perhaps now more than ever a voyage of discovery!

A mere half century ago knowledge of the building blocks of life was rudimentary. But since Watson and Crick's (1953:737) momentous discovery of the now well known double helix structure of DNA,

* Donrich W Jordaan is an advocate of the High Court of South Africa, Head of the Unit for Policy Studies, Centre for International Political Studies, University of Pretoria. 
molecular biology has blossomed, cracking the genetic code, cutting, joining, and moving genes, reading the sequences of bases in DNA molecules, and who can forget Dolly the sheep, the first ever mammal to be cloned from an adult cell (Wilmut, Schnieke, McWhir, Kind \& Campbell 1997:810-813). In April 2000, a company, Celera Genomics, announced that it had sequenced the entire human genome - beating the internationally funded official Human Genome Project with this important phase of the project (Lemonick 2000:51). The next phase, the mapping of the human genome, is now commencing. What was a challenge for the best postdoctoral researchers little more than a decade ago has metamorphosed into everyday work for undergraduates, technicians, and even robots (Kitcher 1996:15). We are indeed witnessing a genetic revolution, which promises to have at least the same profound impact on human society - and therefore on the public policy environment - as did the agricultural and industrial revolutions.

\subsection{Dialogue among civilisations}

Shortly after being voted into office the reformist President Mohammad Khatami of Iran proposed the idea of 'dialogue among civilisations as a paradigm for peace' to the United Nations General Assembly. This inspired the General Assembly to declare 2001 the year of 'Dialogue among Civilisations'. Fate unfortunately took an ironic turn and 2001 became the year of renewed tension among civilisations: 9/11 distorted international public relations and Iran achieved the controversial status of being part of Bush's 'Axis of Evil'.

The idea of dialogue among civilisations however has particular application-value in context of the genetic revolution. Khatami defined the concept 'civilisation' as follows:

[C]ivilisation consists of the material aspects of social life and all institutions and organizations that act as political, economic, industrial, and other frameworks for social organization. (in Bekker \& Pretorius 2001:38)

I submit that the scientific knowledge and technologies associated with the genetic revolution will in the near future drastically and permanently change certain material aspects of social life, for instance procreation. The genetic revolution will therefore usher in a new civilisation, according to Khatami's definition. The subject of this article will be the dialogue between the pre-genetic revolution and postgenetic revolution civilisations. I will therefore be dealing with what Bekker and Pretorius (in Bekker \& Pretorius 2001:10) term the vertical dimension of dialogue among civilisations, denoting the fact that the relevant civilisations do not exist simultaneously, but rather consecutively. 'Dialogue' in this context denotes the public policy discourse that facilitates the transition from the old to the new.

The new post-genetic revolution civilisation will seriously challenge 
our current culture and bioethical values. This challenge transcends current horizontal civilisation frontiers; the genetic revolution will affect all national, ethnic, class and religious groupings. The question is: how well will all of this civilisations-in-the-horizontal-dimension be able to adapt their cultures to deal with the genetic revolution?

This article aims to describe the public policy paradigms of both the pre- and post-genetic revolution civilisations, which will determine the framework for dialogue - public policy discourse - on an abstract conceptual level.

\section{Public policy paradigms}

\subsection{The pre-revolution civilisation: current demarcation of responsi- bility}

Many factors impact on the rearing and eventual ability-levels of a child at the onset of adulthood. In the pre-revolution civilisation, these production-factors, to use economic terminology, could be broadly divided into two categories, namely initial genetic endowment and postconception inputs (Steiner, in Burley 1999:133-150). While initial genetic endowment - your genes - is beyond human control, post-conception inputs include a wide variety of gestational, nutritional, medical and educational factors, which are all man-made or at least mancontrolled. The quality of the two types of production-factors varies considerably between individuals and between nation states, as do the resulting levels of ability (or disability).

For reasons of equality and socio-economic advancement, governments have increasingly taken measures to regulate and even actively to participate in many post-conception inputs: Vaccination against certain illnesses is mandatory, a system of compulsory schooling is enforced, mothers and children are given free medical attention, etcetera. Harmful post-conception inputs, for instance smoking or drug taking during pregnancy, child abuse, and in some reported cases even sub-standard education, are subject to remedial legal action.

On the other hand, initial genetic endowment, as a natural object beyond human control or influence, cannot be subject to governmental regulation or legal remedy. One cannot sue their parents for passing on to them a genetic inclination for obesity or nearsightedness. In the pre-revolution civilisation, a genetic weakness or disability is more often perceived as a constitutive element of the person's personal identity. Such a person cannot complain that they would have been better off without the genetic weakness, because without it they would not exist. If a person is born with a genetic weakness or disability, it is not - from a legal perspective - their parents' fault, but rather because of 
the imperfectness and randomness of nature, or even - as some religious people will view it - the will of a god. In the pre-revolution civilisation, parental and societal responsibility towards children is clearly limited to the second production-factor, namely post-conception inputs.

\subsection{The post-revolution civilisation: Radically expanded responsi- bility}

The genetic revolution will place the determination of children's genetic endowment squarely and completely within the domain of human control: The Human Genome Project will provide us with all the loci of genes and information concerning their common alleles. Parents and their genetic clinicians will be able to obtain a complete genetic profile of any germ cell or pre-embryo, based on which selections can be made for transfer in utero. In a more advanced scenario, mere screening and selection will be transcended by genetic engineering. In the post-revolution civilisation, the two-fold classification of production-factors in initial genetic endowment and post-conception inputs will therefore simply collapse.

A pivotal consequence of the collapse the two-fold classification, is that responsibility for a new child's genetic endowment will shift from nature or the supernatural to man. Once man has plucked and eaten the metaphorical apple from the tree of knowledge, it cannot be undone. There is no return to the blissful ignorance of paradise. Man cannot deny his knowledge and the consequential responsibility it places on him. To tell a child who is about to die a slow and painful death at the age of ten because of a genetic illness, that the genetic illness is the will of nature or the will of god, will in the post-revolution civilisation not suffice.

Genetic adversities will become cause for liability - in the same class or perhaps even worse than other forms of child neglect. Man will have to take up the complete burden of responsibility for the genetic well-being of future generations and transform culture and value systems accordingly. Just as collective resources have been channelled to compulsory public education in recent centuries, collective resources on a state and global scale will have to be channelled to the health and general well-being of future generations.

\section{Paradigm shift and naturalness}

The genetic revolution entails a clear paradigm shift away from nature to human control. The ethical implications of 'naturalness' is therefore central in the dialogue among pre- and post-genetic revolution civilisations. Those who resist the paradigm shift towards taking 
responsibility and who want to entrench current traditions and belief systems argue that the new technologies associated with the genetic revolution are 'unnatural' (contra naturam) and therefore unethical.

Insofar as the term 'natural' denotes a situation as it exists in nature, unaffected by technology, the new technologies associated with the genetic revolution are radical departures from 'natural' sexual reproduction. Intervention in the process of human reproduction other than sexual intercourse has often been attacked on the grounds that it is 'unnatural' and hence unethical. In this argument 'nature' can either refer to 'human nature', or 'the natural processes of life'.

Let us first focus on human nature: Humans are natural toolmakers and tool-users; we are natural manipulators of our world. (Ridley 1998:105-106.) To negate this fact is to sever ourselves from our own nature, to ridicule our own intelligence and to limit ourselves to our most primitive origins. (Susanne, in Susanne \& Stuy 1990:258.) But is it morally justified to apply our natural tool-making abilities to the natural processes of life? Those who would answer in the negative must necessarily perceive the natural processes of life as somehow self-justifying, as inherently good. If this perception is true, the whole medical science should be rejected as an immoral interference with the self-justifying, inherently good natural processes of life. Ridley demonstrates the consequences of this perception:

Cure diseases? No: Diseases are part of the natural process of life. Ease the pain of cancer? No: It's natural that cancer should be painful. Rebuild a shattered limb? No: Shattered limbs should stay naturally in bits (1998:106).

There is nothing necessarily good about what is natural. It must, however, be remembered that for the entire existence of our species, the random determining of a new human being's genotype has been shrouded in mystery; only now is it being demystified. The perception of the natural processes of life concerning human procreation as mystically self-justifying has been reinforced over millennia.

There is, however, no rational foundation for such a perception. More often than not, 'natural' is merely a disguise for prejudice and tradition. As McCarthy (1999:98-104) remarks, the unnatural-label has been used to condemn inter-racial marriage, various kinds of sexual activities, etcetera, and is only worth bringing into the open to be dismissed as an argument of ethical significance.

\section{The mystification paradox}

The successful transformation of cultures to the post-revolution civilisation will largely depend on the general public and public policy makers' clear understanding of genetics. Our general knowledge and perception of genes and genetics are crucial aspects of the dialogue

TD, 2(2), December 2006, pp. 369-378. 
among the pre- and post-genetic revolution civilisations. A major obstacle in the way of successful dialogue is a phenomenon that I call the mystification paradox. It can be explained as follows: as the genetic revolution is increasing our scientific understanding of the fundamental mechanisms of life, so these mechanisms are being demystified; but simultaneously a variety of factors, for instance the fact that this new science seems to penetrate the very essence of life, as well as the existence of a new esoteric genetic terminology that is inaccessible to the general public (Susanne, in Susanne \& Stuy 1990:203, 211), mystify genetics. This paradoxical mystification of genetics by the genetic revolution deserves closer analysis.

\subsection{The mystification of genetics: genetic reductionism}

John Avise begins the first chapter of his book The genetic gods as follows:

They mastermind our lives, influencing our physical appearance, health, behavior, even our fears and aspirations. They constitute our material reason for being $3 / 4$ for eating and sleeping, warring and loving, hating and caring, forging relationships $3 / 4$ for procreation. To them we owe our existence ... They give us life, yet dictate senescence and death. "They" are not gods, but our genes. Describing genes as "gods", however, is particularly apt (1998:3).

He points out three similarities between gods and genes:

1) Genes have special powers over human lives and affairs;

2) Genes exert influence over the course of nature; and

3) Gene lineages are potentially immortal, and demonstrably so over billion-year time scales.

The god-status of genetics in general owes a lot to expectations created by the genetic revolution. The message to the public is simple: We can put our faith in genetics - it will provide wondrous new cures for previously incurable diseases:

The Human Genome Project... will revolutionize the detection, prevention and treatment of conditions from cancer to depression to old age itself (Begley 2000:30-31).

and

[T] he imminent mapping of the human genome ... could lead to rapid advances in treating heart disease, cancer, Alzheimer's and perhaps even AIDS (Time 8 November 1999:33).

The media plays a primary role in the mystification of genetics. With reference to the sequencing of the human genome almost finished, Newsweek (Begley 2000:30-31) reported that soon "science will know the blueprint of human life, the code of codes, the holy grail, the source code of Homo sapiens". Make no mistake - this is stuff of legend: Images of Arthur's quest knights relentlessly searching for years on 
end for an elusive sacred artefact; "code of codes" can just as well refer to some religion's ancient holy scripture; and "blueprint for human life" conjures up images of genesis: In the beginning God created...

Other sciences and technologies may have varying degrees of impact on human existence, but genetics seems to impinge on the essence of life itself. The sociologists Dorothy Nelkin and Susan Lindee (1995:4142) describe it well:

DNA appears in popular culture as a soul-like entity, a holy and immortal relic, a forbidden territory. The similarity between the powers of DNA and those of the Christian soul, we suggest, is more than linguistic or metaphorical. DNA has taken on the social and cultural functions of the soul. It is the essential entity $3 / 4$ the location of the true self.

Because of this mystification of genetics, humans seem to be reduced to their genes. Newsweek (Begley 2000:32) quoted a Harvard scientist as remarking with reference to the completion of the sequencing of the human genome, that then science will know "what it is to be human." We are our genes - our expectations about each other's accomplishments; our suspicions about each other's faults are all centred on our genes. This genetic reductionism (or genetic determinism) is strongly reminiscent of the role society used to give to the soul or a god in human affairs - the soul as the essence of a person and a god as the determinating force in human affairs. The coalescence of genetic reductionism and the mystification of genetics are therefore not surprising.

Avise makes the following thought-provoking observation:

Indeed, over the last century, the genetic gods would seem to have wrestled from the supernatural gods considerable authority over human affairs. Does any room remain for a metaphysical god? (1998:204)

\subsection{The genetic gods in perspective: nature versus nurture}

Although I will not speculate as to the room left for a metaphysical god in human affairs, I will surely expose the myth of genetic reductionism - in the words of the Advisers to the President of the European Commission on the Ethical Implications of Biotechnology: "We are not just our genes (1997:351)."

Reducing the character and accomplishments of an individual to his or her genotype is an extremely narrow perspective on human nature. Harris remarks, "it may be that 'manners maketh man' but genes most certainly do not (1999:78)." The reality, however, is far more complex: most human traits - and specifically personality - are the result of the intricate interaction between multi-genes and the environment (Gardner, in Burley 1999:35; Juengst, in Agius \& Busuttil 1998:95-96; Kitcher 1996:251; Renzong, in Agius \& Busuttil 1998:112;

TD, 2(2), December 2006, pp. 369-378. 
Silver 1999:250). How certain human traits are influenced by genotype vis-à-vis environment, is generally referred to as the "nature-nurture debate'. While acknowledging the complexity of the subject, I will attempt briefly to illustrate the interaction between genes and environment with the following example: A1 and A2 are siblings with similar alleles at the genes relevant to this example, as are B1 and B2. A1 and B1 are brought up in very similar ways, yet A1 has a gifted IQ while B1 scores average in IQ tests. Likewise, A2 and B2 are reared very much alike, but quite differently from $\mathrm{A} 1$ and $\mathrm{B} 1$, and both score average in IQ tests. Does this scenario reveal a genetic basis for intelligence?

In one sense yes: $\mathrm{A} 1$ and $\mathrm{B} 1$ share the same environment, but A1 intellectually excels above B1. Clearly, the determining factor is their different genotypes. Yet, on the other hand, an environmental basis for intelligence can just as easily be deduced from the scenario: A2 has the same genetic endowment as A1, but does not fare nearly as well as A1 in IQ tests! The crucial factor in the nature-nurture debate therefore depends on whether the focus is on the difference between $\mathrm{A} 1$ and $\mathrm{A} 2$, or between $\mathrm{A} 1$ and $\mathrm{B} 1$.

The temptation, of course, is to think that demonstrating that genetic differences make the difference in some environments amounts to demonstrating that they make the difference in all standard environments, moving on to the conclusion that genes are therefore destiny. The mystery and wonder of genetics make this false conclusion all the more seductive, yet it remains false.

Finally, mention must also be made of our species' capacity for free volition: Even if a person is born with an innate talent in music, mathematics, or athletics, it will not be enough to turn that person into a musician, a mathematician, or an athlete, if that person chooses to ignore the good starting points in his or her genes. Aside from genetic and environmental influences, a lot depends on an individual's determination and hard work.

The interplay between free will, environment and genes is an immensely complex subject, but for purposes of this paper this discussion should suffice. Silver encapsulates the basics well:

Environment and genes stand side by side. Both contribute to a child's chances for achievement and success in life, although neither guarantees it (1999:264).

\section{Conclusion: The importance of education}

At the beginning of this article I posed the question: how well will all the civilisations-in-the-horizontal-dimension be able to adapt their cultures to deal with the genetic revolution? Khatami (in Bekker \& 
Pretorius 2001:52-62) has referred to the Muslim civilisation's current problem with transforming their culture and traditions to the capitalist Western civilisation. In the case of the post-genetic revolution civilisation, with its radically expanded responsibilities to future generations, both East and West will have to transform age-old traditions, value-systems and religious dogma. As Khatami (in Bekker \& Pretorius 2001:41) reminds us, religious interpretations - even if they are entrenched in centuries of tradition - are relative to time and space and never absolute.

Since any process of rational public policy formulation and sensible public debate are based on knowledge of the subject, biological education - on a global scale - is essential to the demystification of the genetic revolution. South Africa's constitutional commitment to the open society, which entails rational decision-making (Jordaan 2001:107-114), is very relevant in this context. This need for public education has been widely recognized - by the Council of Europe (Council of Europe 1992:285) and the American National Bioethics Advisory Commission (1997:v) to name but a few. The South African government also recognised this need and in 2003 established the Public Understanding of Biotechnology (PUB) programme under the auspices of the National Research Foundation, which has been remarkably active during its short existence (see www.pub.ac.za).

The media, with its crucial role in forming public opinion and hence in legitimizing science (Weingart 1998:869-879), has all too often given in to sensationalism, instead of empowering people with knowledge about the genetic revolution (Susanne, in Susanne \& Stuy 1990:202; Benagiano \& Bianchi 1999:868). This situation places even more weight on the shoulders of national governments, as the primary role-players in the public education to allocate enough resources to empower their people with accurate scientific knowledge. Education provides the essential platform for dialogue among the pre- and post-genetic revolution civilisations.

\section{Bibliography}

Advisers to the President of the European Commission on the Ethical Implications of Biotechnology. 1997. Ethical aspects of cloning techniques. Journal of Medical Ethics, 23:349-352.

AGIUS, E. \& Busuttil, S. Editors. 1998. Germ-line intervention and our responsibilities to future generations. Dordrecht: Kluwer Academic Publishers.

AVISE, J.C. 1998. The genetic gods. Cambridge, Massachusetts, USA: Harvard University Press. 
BEGLEY, S. 2000. Decoding the human body. Newsweek, 10 April: 30-37.

BEKKER, T. \& Pretorius, J. eds. 2001. Dialogue among Civilisations: A Paradigm for Peace. Pretoria, South Africa: Unit for Policy Studies, Centre for International Political Studies, University of Pretoria.

BENAGIANO, G. \& Bianchi, P. 1999. Sex preselection: An aid to couples or a threat to humanity? Human Reproduction, 14:868-870.

Beyond 2000: Your body, our planet. 1999. Time, 8 November:32-88.

BURLEY, J. Editor. 1999. The genetic revolution and human rights. New York: Oxford University Press.

COUNCIL OF EUROPE. 1992. Recommendation No R(92)3 on Genetic Testing and Screening for Health Care Purposes. International Digest of Health Legislation, 43:284-289.

HARRIS, J. 1998. Clones, Genes, and Immortality. New York: Oxford University Press.

JORDAAN, D.W. 2001. The Open Society. Journal for Contemporary Roman Dutch Law, 64:107-114.

KITCHER, P. 1996. The Lives to Come. London: Penguin Books.

LEMONICK, M.D. 2000. Victory for Venter. Time, 17 April:51.

MCCARTHY, D. 1999. Persons and their copies. Journal of Medical Ethics, 25:98-104.

NATIONAL BIOETHICS ADVISORY COMMISSION. 1997. Cloning Human Beings: Executive Summary. Rockville, Maryland, USA.

NELKIN, D. \& Lindee, M.S. 1995. The DNA mystique: The gene as a cultural icon. New York: W.H. Freeman.

RIDLEY, A. 1998. Beginning Bioethics. New York: St. Martin's Press.

SILVER, L.M. 1999. Remaking Eden. London: Phoenix.

SUSANNE, C. \& Stuy, J. Compilers. 1990. Bio-etiek. Brussels: VUB Press.

WATSON, J.D. \& Crick, F. 1953. A Structure for Deoxyribose Nucleic Acid. Nature, 25 April:737.

WEINGART, P. 1998. Science and the media. Research Policy, 27:869879.

WILMUT, I., Schnieke, J., McWhir, J., Kind, A. \& Campbell, K.H.S. 1997. Viable offspring derived from fetal and adult mammalian cells. Nature, 385:810-813. 